\title{
Ecuador: return from migration and entrepreneurship in Loja
}

\author{
Silverio Alarcón and Jessica Ordónez
}

SUMMARY

\begin{abstract}
Drawing on data from a survey of returning migrants, this study examines the factors behind the decision to launch a business in Loja, Ecuador. The possible explanations fall under various headings: demographic characteristics, work experience abroad, reasons for returning, current situation, intention to re-emigrate, and activity before, during and after migration. The study also considers different concepts of "entrepreneur", as own-account worker and as employer. The results are analysed, first, using univariate tests and then estimating probit models. The variables most closely associated with a high probability of starting a business after returning from migration are entrepreneurial experience during the migration, and the fact of having returned voluntarily, as well as having worked in the host country in agriculture or the hospitality sector. Having university training and having worked in public administration before migrating are negative factors. Other influential variables are age and the wage or salary received abroad, but these are more nuanced.
\end{abstract}

KEYWORDS

JEL CLASSIFICATION

AUTHORS
International migration, return migration, small enterprises, migrants, entrepreneurship, surveys, econometric models, Ecuador

F22, J61, L26

Silverio Alarcón is a professor in the Department of Agrarian Economics, Statistics and Business Management of the Polytechnic University of Madrid, Spain. silverio.alarcon@upm.es

Jessica Ordóñez is a teacher and researcher with the Department of Economics of the Universidad Técnica Particular de Loja, Ecuador. jaordonezx@utpl.edu.ec 


\section{I}

\section{Introduction}

There are two-way linkages between the economy and migratory phenomena. Thus, economic crises or situations of poverty are the primary motivation for the decision of many individuals and families to emigrate to more prosperous countries. Migrants, for their part, are a key factor in the economic growth of their countries of destination, as they boost production capacity and they expand aggregate demand for goods and services. They also contribute to economic development in their home country, primarily by sending regular remittances to their families. Another contribution to economic development of the home country occurs when migrants return, bringing with them their experience, their savings or their entrepreneurial drive. This study focuses on return migration in Loja, Ecuador, and on aspects relating to the capacity to launch and develop a business.

Over the last two decades, migratory flows in Ecuador have been linked to two major crises. First, the dollarization of the economy in 1999 generated a progressive and massive exodus of Ecuadorians in the late 1990s and during the first decade of the 21st century (Vono, 2011). Loja contributed significantly to this wave of emigration: for example, it fielded $16 \%$ of the Ecuadorians who went to Spain, behind only Pichincha with 30\% (Correa, 2010). Subsequently the world crisis of 2008, which hit the United States and Europe particularly hard, sparked a return flow of many migrants back to Ecuador. Nevertheless, numerous migrants had returned voluntarily to Ecuador before this crisis. As to the categories of returnees, the International Organization for Migration (IOM) reports that returns occur for the most part in three different ways (IOM, 2006): (i) voluntary without compulsion, when migrants decide at some point during their stay abroad to return to their country of origin of their own free will and at their own expense; (ii) voluntary but under compulsion, when persons are at the end of their temporary protected status, rejected for asylum, or are unable to stay and choose to return at their own volition; and (iii) involuntary, as a result of a deportation order

$\square$ This study was financed by the Development Cooperation Directorate of the Polytechnic University of Madrid, in the Eleventh Competition for Subsidies and Grants for Activities in University Cooperation for Development (2010). issued by the authorities of the host country. This study is based on a survey of returnees conducted in 2012, and covers categories (i) and (ii), i.e. those who returned to Ecuador voluntarily and without compulsion, for whom return marks the completion of their migration project; and those who returned under compulsion because of the deteriorating economic situation, and who do not discard the possibility of emigrating again when the crisis is over.

The study addresses the conditions that lead migrants to start a business upon their return. They may well be in a position to contribute financial resources or working experience acquired abroad in ways that will foster local development by introducing innovations, generating jobs, and promoting new forms of organization. However, it is also possible that returnees will not contribute to development because they were working in unskilled jobs, they have received no training, or they fail to employ their savings in productive investments (Gmelch, 1980). As there is no consensus on the relationship between return and entrepreneurship, and as there are few studies that focus on Latin America, it is useful to examine evidence on the circumstances that enable returnees to promote the development of their home regions (Alarcón and Fernández, 2013). Accordingly, this article seeks to identify the socioeconomic characteristics of migrants returning to the Canton of Loja in Ecuador, with special emphasis on the businesses started after their return and on the factors related with the decision to start a business.

We examine the extent to which the conditions of life abroad and those of return contribute to entrepreneurship. Specifically, we analyse the relationship between entrepreneurship and characteristics such as gender, age, civil status, level of education, situation abroad (host country, wage level, duration of stay, training received and business experience), conditions of return, current situation in Ecuador, and occupational activity prior to emigration and while abroad. This practical knowledge can help with the design of programmes and strategies that will favour the most productive aspects of return (IOM, 2010; López de Lera and Pérez Caramés, 2013).

This article adopts a broad concept of entrepreneurship that embraces any attempt to start a new business, such as self-employment, creation of a firm, or expansion of an existing business (Kelley, Singer and Herrington, 
2012). However, as their contributions to development are different, we have considered two levels of analysis: independent or own-account workers and employers. The first refers to an independent activity that a person might undertake because of the difficulty of finding work; the second relates to small enterprises with employees, which will have a greater impact on local development. Distinguishing between these two types allows us to identify their different profiles, as well as the public policies that can be targeted at each of them.

\section{II}

\section{Background}

Ever since Ravenstein (1885) there has been a growing interest in return migration. The most frequent issues, such as economic impacts, internal circulation, returning retirees and return for ethnic reasons, have been expanded to include new matters such as the psychological and social effects on returnees, reintegration, students and qualified professionals returning to pursue a business career, studies that take a comprehensive approach to economic and sociocultural effects, and return and its linkages with various transnational aspects (Fernández Guzmán, 2011).

Studies on return migration have evolved from a general to a more specific focus. Thus, Lee (1974) studied internal return migration in the United States in the 1960s and $70 \mathrm{~s}$, and found that there were differences in the propensity to return and in the effects of return, related with age, sex, race and locational factors such as urban or rural origin. Glaser and Habers (1974) analysed the reasons for remaining or returning, as cited by skilled migrants from developing countries: economic and social motives such as the possibility of greater incomes or more attractive jobs are associated with the decision to stay, while return is related with family, friends, a sense of patriotism, or ethnic or racial discrimination. Cerase (1974) studied return migration from the United States to the South of Italy and produced an interesting typology of the various cases: returnees may be motivated by failure (those who cannot adapt to the host country); by "conservatism" (those who use their savings, for example, to buy land and take up farming back home); by retirement (those who return home to spend their retirement years); and by innovation (those who transfer their know-how and professional experience upon their return to their region of origin).
The article is structured as follows: in the next section we put this research in context, summarizing the literature on return migration; we describe in detail the survey conducted, we discuss the socioeconomic characteristics of the migrants, the situation in the host country and the reasons for returning, and we compare this information for the groups of entrepreneurs and non-entrepreneurs. We then relate the specification and the most important aspects of the econometric model and discuss the results obtained. The article ends with a statement of conclusions.

Gmelch (1980), in addition to reformulating the typologies of returning migrants, reviews the consequences of return migration in the regions of origin. It is frequently the case that returnees have been engaged in unskilled work and have received no training of any kind, and consequently their impact on the local economy upon their return may not be very significant. In other cases, where they have acquired professional experience that could generate value added, it may be difficult to apply that experience in the rural areas to which they return, because of lack of infrastructure. As to how they apply their savings, in the majority of situations they use them not in productive undertakings but rather in building homes and boosting the consumption of current goods. Gmelch notes some examples of returnees who promote social change (the "innovation" return of Cerase, 1974) but he recognizes that they are not the majority.

Until the 1990s, research was conducted primarily in Europe and the United States, and it focused on those geographic areas (Fernández Guzmán, 2011). In the decade of the 90s, however, new contributions began to appear from Africa, Asia and the Pacific Islands. Thus, the work of Premachandra (1990) provides evidence from Sri Lanka as to how the skills acquired by migrants abroad may not be applicable to the family business environment upon their return.

In a study of French Polynesia, Lockwood (1990) casts doubt on the long-term economic viability of the development projects undertaken by returning migrants, given demographic growth and the scarcity of land in those islands.

Muschkin (1993) studies the labour market for returnees from the United States to Puerto Rico, based 
on population censuses during the 1970s and 1980s. Logistic regression estimations offer evidence that returnees face greater difficulties in finding work than do non-migrants.

Thomas-Hope (1999) analyses this phenomenon in the case of Jamaica, highlighting the institutional climate of trust as an element facilitating return, as well as the importance of the positive sociocultural impact of returnees on that country. From a gender focus, Gmelch and Gmelch (1995) conclude that women obtain less satisfaction than men upon their return, because their employment opportunities are fewer.

The 1990s also saw studies for African countries, such as that prepared by Diatta and Mbow (1999), who found that developing the potential of returning migrants had a positive effect in the case of Senegal. Chandra (1997) illustrates the transitory nature of the migration of a Patidar community from Gujarat (India) to Kenya, and its impact on improving their social status. Nadeem shows that returnees prefer non-agricultural self-employment to wage work.

Recent years have seen the emergence of analyses of social networks and transnational linkages, as well as the neo-institutional perspective (Fernández Guzmán, 2011). The link between migration and development has been confirmed, and international agencies (World Bank, International Monetary Fund, Inter-American Development Bank) have categorized the role of returnees and remittances as key elements in modernizing their regions of origin (Olesen, 2002). Constant and Massey (2002) use German data to test two theoretical models that establish different motives for undertaking international migration, and they find evidence for both. This leads to the conclusion that migrants are heterogeneous and consequently that we cannot generalize any single vision of return migration. Again using German data, Hunt (2004) analyses the heterogeneity of migrants in terms of their qualifications, which determines their success or failure in the host country, and consequently their return. Amuedo-Forantes and Pozo (2006) have studied the relationships between remittances and entrepreneurial ventures in the Dominican Republic.

Focusing on the return-entrepreneurship connection, the factors most frequently studied relate to the particular features of the stay abroad, and especially to the savings accumulated, the duration of stay, and the work experience acquired. In this regard, Ilahi —in a 1999 study on migrants returning to Pakistan - shows that they have a high tendency towards non-agricultural self-employment, thanks to savings accumulated in the host country; McCormick and Wahba (2001) show for
Egyptian returnees that the probability of becoming an entrepreneur increases with the length of stay and with savings; Black and Castaldo (2009), in their study of Ghana and Côte d'Ivoire, find that the factor contributing most to entrepreneurship by returnees is work experience abroad, although other factors such as accumulated savings, the reasons for return and the frequency of visits to the home country, are also significant; Piracha and Vadean (2010) explore the impact of returnee status on working situation in Albania, distinguishing between those who take up self-employment and those who start a business with employees, and they find that entrepreneurship is positively related to schooling, foreign-language proficiency, and savings accumulated abroad; and Démurger and Xu (2011), find that in the Chinese province of Anhui returnees are more likely than non-migrants to become entrepreneurs, and that likelihood is enhanced both by savings and by the change of occupation in the country of destination.

However, other studies adopt slightly different strategies. Thus, Gubert and Nordman (2011) consider a broader set of explanatory variables, and they show for North Africa (Morocco, Algeria and Tunisia) that entrepreneurial returnees are typically young men with an average education level and that the probability of becoming an entrepreneur after return is greater for returnees with initial experience as an entrepreneur or independent worker, for those who received job training abroad, and for those who made a free and independent decision to return. Montoya, Salas and Soberón (2011), in a study of migrants returning to Mexico, highlight the fact that a portion of returnees have retained the occupational trade they performed abroad, others have acquired new skills that allow them entry to different labour markets, and some of them devote themselves to their new businesses, i.e. migration to the United States gave them the means to capitalize and create a business. Marchetta (2012) finds, in a study on Egypt, that the status of returned migrant increases the probability that the business venture will survive. And the work of Wang and Yang (2013) in rural China shows that the experience of migration enhances the possibilities of paid employment upon return, but has a negative impact on entrepreneurial activities.

When it comes to Ecuador, there is little empirical research available on return migration. The studies we examined were conducted by Cristian Vasco and Christian Schramm.

Vasco (2011) uses the Survey of Living Conditions 2005-2006 to detect factors associated with the probability that a rural household in Ecuador will 
have a rural business or will generate non-agricultural employment. The results show that there is no impact from international migration or from remittances, but that there is indeed an impact from education, credit, and access to basic services. On the other hand, migration boosts the number of household members employed in a rural business.

Schramm (2011) stresses the importance of transnational social networks, and on this basis offers a typology of returnees and their migration history. The data used are drawn from interviews with experts from various organizations and with returning migrants in the cities of Quito, Cuenca and Loja in 2008. The results point to three types of migrants, depending on the decision to emigrate and to return. Type I — "constant" migrants - emigrate with a very specific objective and the clear idea of a temporary stay in Spain, and so for them return is a logical consequence of a migration plan in which the intention to return to Ecuador has always been present. For type II —_failure-driven" migrants - leaving is more on their minds than returning, and so their decision to return tends to reflect a lack of stability, of economic capital and of prospects in the host society. Type III - the "seekers" - hope to make a new beginning through migration, to find a new life abroad, and in this case the return was not anticipated and is likely associated with external forces that make it unavoidable.

In light of these background factors, Ecuador offers a fertile field for future research on return migration.

\section{III}

\section{Survey of returnees in the Canton of Loja}

The 2012 survey of returning migrants in Loja (Alarcón and others, 2013) involved 98 returnees. The Canton of Loja, capital of the Province of Loja, is home to $79 \%$ of the province's total population, according to the Population and Housing Census of the National Statistics and Census Institute (INEC, 2010). That same census showed that $89 \%$ of the population of the canton emigrated, and that $98 \%$ of them were from the urban area. This justifies the use of a sample in this canton, focusing primarily on the urban area. The interviews were conducted in the parishes with the greatest migration flows: San Sebastián, El Valle, Sucre and Sagrario (urban) and Vilcabamba and Malacatos (rural).

Sampling posed some problems, due to the complexity of identifying the number and location of migrants returning to Ecuador, as there are no statistics, either public or private, national or regional, on this topic. To gain an approximation of the weight of returning migrants in Loja vis-à-vis the country as a whole, we conducted the following exercise, taking as reference the 2010 census: the questionnaire accompanying that census contained questions as to where the respondent was born and where he or she lived in the last five years, and included the option "abroad". This made it possible to identify persons who were born in some province of Ecuador but had been living abroad five years earlier. With this approximation to the concept of "returnees", we calculate that $8 \%$ of the population of Loja fell into that category.
From this perspective, we used the "snowball" sampling method, whereby the participants initially selected provide referrals to others who meet the eligibility criteria. The resulting sample is adequate in cases of difficult access, as in the case of returnees where there is no census or list to identify them. As this is a non-probabilistic sample, the possibility of bias is great. Following the recommendations of Biernacki and Waldorf (1981) we took special care in the initial selection and in guiding the growth of the sample so as to control the variability of the participants and guarantee that the sample would be representative of the population of returnees. In this type of sampling it is the analyst who decides the final number of members included in the group. In the end, 98 interviews were conducted.

The questionnaire consisted of the following sections:

(i) Personal information: gender, age, civil status, level of education, and so forth.

(ii) Career abroad: origin and destination of migration, motives, timing, labour activity, average wage, entrepreneurship or other.

(iii) Return: motives, timing, perceived changes or other.

(iv) Current situation: place of residence, degree of satisfaction with the return, labour activity, entrepreneurship, financing, assistance, and so on.

(v) Re-emigration: readiness to re-emigrate. 


\section{Socioeconomic characteristics, destination and motives for migration and return}

Table 1 presents information on the characteristics of the returnees. The questionnaire was administered to a greater proportion of women (54\%) than of men (46\%), and the respondents were most frequently married $(65 \%)$. The age structure shows the greatest concentration among persons 29 to 44 years ( $52 \%$ ), followed by those over 45 (38\%). In terms of education level, a significant portion of the respondents have a university education $(42 \%)$ but important groups have only secondary (38\%) or primary (19\%) schooling.

The principal migration destination of those surveyed, by far, was Spain (73\%), followed by the United States and the United Kingdom (12\% each), and finally Italy (2\%) (see table 1). Of the respondents, $82 \%$ had stayed abroad for more than nine years.

Before leaving Ecuador, the majority of respondents $(81.6 \%)$ had lived in urban areas, as opposed to $18.3 \%$ in rural areas (see table 2). After return, the urban proportion rose $(86.7 \%)$ while the rural fell $(13.2 \%)$. Table 2 shows the urban/rural transition between exit and return. Most returnees returned to the same environment, and those who changed did so primarily from rural to urban.

Over half $(64 \%)$ of the migrants were working before they left (see table 1), but nevertheless $89 \%$ of them emigrated for economic reasons, and to a much lesser extent for family reunification (10\%) and other reasons. Low wages and precarious employment opportunities in the Loja labour market may thus have influenced the decision to migrate. The reasons for returning are many, including reunification with relatives $(62 \%)$ and the unstable economic situation in the country of destination (17\%), while illness (7\%), spontaneous decision (7\%) and legal problems (5\%) figured less prominently.

Migration generates effects in various areas: economic, social and cultural. The economic effects seem to be the most visible, as returning migrants employ part of their saving to acquire assets such as houses, land or vehicles. Thus, $69 \%$ of respondents said that, upon their return, they enjoyed a better quality of life or greater comforts (4\%) or access to private education (7\%), while $19 \%$ said they had experienced no economic change. Only $8 \%$ said they were in receipt of some kind of income or assistance from the host country. The cultural effects have to do primarily with dietary changes $(35 \%)$, and more than half declared they had undergone no change (in manner of dressing, religion, musical tastes or other) during their stay abroad. The social effects become evident in situations where children are performing poorly at school, or in cases of family break-up or psychological problems (see again table 1).

\begin{tabular}{|c|c|c|c|c|}
\hline \multicolumn{5}{|c|}{ Gender } \\
\hline Men & Women & & & \\
\hline 45.9 & 54.1 & & & \\
\hline \multicolumn{5}{|c|}{ Civil status } \\
\hline Single & Married & Divorced & Widowed & Cohabiting \\
\hline 12.3 & 65.3 & 12.3 & 3.1 & 7.1 \\
\hline \multicolumn{5}{|c|}{ Age (years) } \\
\hline $15-28$ & $29-44$ & 45 and over & & \\
\hline 10.2 & 52 & 37.8 & & \\
\hline \multicolumn{5}{|c|}{ Education ${ }^{\mathrm{a}}$} \\
\hline Primary & Secondary & Higher (university) & Postgraduate & \\
\hline 19.4 & 37.8 & 41.8 & 1.0 & \\
\hline \multicolumn{5}{|c|}{ Destination } \\
\hline United States & Spain & Italy & United Kingdom & \\
\hline 12.3 & 73.5 & 2.0 & 12.3 & \\
\hline
\end{tabular}


Table 1 (concluded)

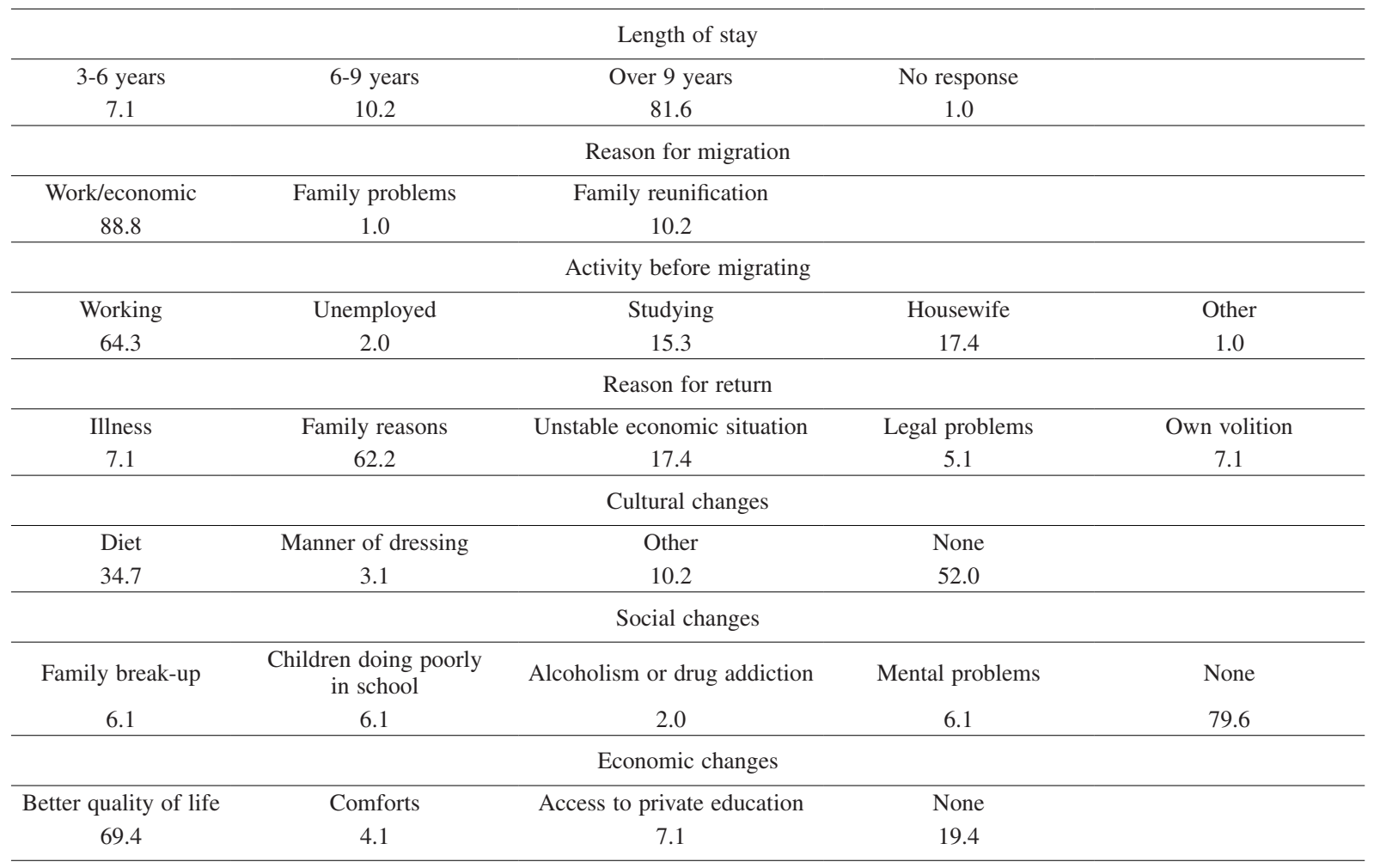

Source: S. Alarcón and others, Características socioeconómicas de los migrantes retornados en Loja (Ecuador), Madrid, Polytechnic University of Madrid, 2013 [online] http://blogs.upm.es/gedr/wp-content/uploads/sites/22/2014/06/Migrantes-Retornados-Loja.pdf.

a Refers to those who have completed the respective level of education or have obtained the respective certificate.

TABLE 2

Urban-rural transitions before
and after migration
(Percentages)

\begin{tabular}{llrcc}
\hline & & \multicolumn{3}{c}{ After return } \\
\cline { 3 - 5 } & & Urban & Rural & Total \\
\hline \multirow{3}{*}{ Before migration } & Urban & 79.6 & 2 & 81.6 \\
& Rural & 7.1 & 11.2 & 18.3 \\
& Total & 86.7 & 13.2 & \\
\hline
\end{tabular}

Source: S. Alarcón and others, Características socioeconómicas de los migrantes retornados en Loja (Ecuador), Madrid, Polytechnic University of Madrid, 2013 [online] http://blogs.upm.es/gedr/wpcontent/uploads/sites/22/2014/06/Migrantes-Retornados-Loja.pdf.

\section{Business ventures of returning migrants}

The variable of interest in this study is the proportion of returning migrants who have undertaken a business venture either as workers on their own account or as employers. In the survey that proportion is $44 \%$, and employers represent around $20 \%$ of this figure. The remainder of respondents are classified in two groups: those who have found paid employment $(24 \%)$ and those who are unemployed (32\%) because they have neither found work nor decided to launch an enterprise. Among those in paid employment, a third are government employees and two thirds are working for private firms.

The incomes earned from each of these activities differ widely. Thus, government employees are in receipt of the largest incomes, between US\$ 350 and US\$1,000 a month, with US\$564 as the average. Next come the entrepreneurs, with an average income of US\$ 360 a month: there is however greater variability within this group, and $33 \%$ of them say they receive no income at all. Lastly, private employees receive an average of US\$ 254 a month.

Table 3 shows the proportion of entrepreneurs and non-entrepreneurs according to their characteristics. For each section of the survey we selected those variables 
of greatest interest or capacity for generating business ventures (Gubert and Nordman, 2011). We also conducted chi-squared or Kruskal-Wallis tests to see whether differences could be identified between entrepreneurs and non-entrepreneurs according to these characteristics. At first glance, the factors that most influence business ventures are those included in the career abroad and upon return categories.

Although we found that the proportion of women entrepreneurs was greater than that of men, the test indicates that there are no significant differences between the two. Nor are there differences by age or level of education in terms of entrepreneurship, although civil status does seem to have an influence. Thus, being married has a positive effect on the decision to launch a business, which suggests that collaborative work, emotional stability or both are key elements for assuming risks and undertaking projects.

Although the test with all categories of migratory destination shows no significant differences, this is not the case for the United States. Returnees from that country have a greater rate of entrepreneurship upon return than those returning from Spain, Italy or the United Kingdom.

The wage received in the host country is one way of approximating the savings capacity of returnees, and it can increase the capacity to access financial resources for launching a business. In the sample, wages are on average higher among entrepreneurs, but this is so variable as to rob it of significance.

The variables of having spent more than nine years abroad and having received training are not significant, but by contrast the variable of having been an entrepreneur during the stay abroad is significant. Nearly all migrants worked as paid employees, and only a small portion started a business abroad. The majority of those who had or acquired entrepreneurial experience while abroad repeat their experience in their place of origin, and they frequently become employers. Thus, of all the variables analysed in table 3 , entrepreneurial experience abroad is the one that turns out to be most significant as a difference between the two groups.

The Kruskal-Wallis statistic, at 8.07, is one of the highest in table 3, and rises even more if self-employment is excluded from the employers variable. Expressed in terms of the original figures from the sample, 10 Lojanos had a business while abroad and of these, one is working as an employee in a private firm, three are working on their own account without employees, three have an enterprise with fewer than 10 workers, and three have created an enterprise with more than
10 workers. The sample contains only three employers with a firm employing more than 10 workers, and those three were already entrepreneurs during their stay abroad. Thus, everything seems to indicate that entrepreneurial experience abroad is decisive for generating employment upon return.

The reason for returning is also important, as more than half of those who returned voluntarily (for family reasons or by their own decision) decided to launch a business. However, when the cause was illness, most ended up as unemployed; when they returned because of the unstable economic situation, their labour status is equally divided among paid employees, entrepreneurs and jobless; and in the case of return because of legal problems, the principal occupation is as a paid employee.

Another influential factor is the time that has elapsed since return. The category of those who returned more than nine years ago numbers 21 returnees: 13 of them have launched a business, and only three are working for their own account without employees. The remainder are managing businesses with fewer than 10 workers. Consequently, starting a business is an alternative when one does not find paid employment, but it is also a way of earning higher incomes and getting rich. The passage of time is revealed as decisive for enterprises to take root and grow.

The factors that describe the current situation do not indicate any difference in behaviour between entrepreneurs and non-entrepreneurs. Thus, the majority of returnees $(88 \%)$ say they are satisfied with their return, and the proportions are similar in both groups. Knowledge of migration support institutions has been represented through the variable "is familiar with the National Secretariat for Migrants (SENAMI)", to which only a quarter responded affirmatively, indicating a tenuous integration into society. To the question as to whether they would be prepared to accept help from SENAMI, $45 \%$ (divided evenly between entrepreneurs and non-entrepreneurs) said yes, $23 \%$ said no, and $32 \%$ fell into the "don't know" or "no response" categories. This unwillingness or indifference with respect to government actions could be interpreted to mean that returnees do not think such help necessary, or perhaps they are dubious about bureaucratic procedures or the counter-obligations they would have to undertake.

We have already noted that a minority $(12 \%)$ were unhappy with their return. Yet there is a higher proportion ( $41 \%)$ that would be prepared to re-emigrate. There are even some entrepreneurs who would like to go abroad again, although in fewer numbers than non-entrepreneurs. 
TABLE 3

Characteristics of returnee entrepreneurs

(Percentages of the total sample)

\begin{tabular}{|c|c|c|c|c|c|}
\hline & Entrepreneur & Non-entrepreneur & $\begin{array}{l}\text { chi-squared statistic } \\
\text { (Kruskal-Wallis) }\end{array}$ & $p$-value & $\begin{array}{l}\text { Homogeneity } \\
\text { rejected }\end{array}$ \\
\hline \multicolumn{6}{|l|}{ I. Demographic characteristics } \\
\hline Sex & & & 0.01 & 0.9174 & NO \\
\hline Male & 20.4 & 25.5 & & & \\
\hline Female & 23.5 & 30.6 & & & \\
\hline Age (years) & & & 2.56 & 0.2777 & NO \\
\hline $15-28$ & 2.0 & 8.2 & & & \\
\hline $29-44$ & 24.5 & 27.6 & & & \\
\hline 45 and over & 17.4 & 20.4 & & & \\
\hline Civil status & & & 8.44 & 0.0766 & $*$ \\
\hline Single & 2.0 & 10.2 & & & \\
\hline Married & 33.7 & 31.6 & 4.38 & 0.0364 & $* *$ \\
\hline Divorced & 4.1 & 11.2 & & & \\
\hline Consensus union & 4.1 & 3.1 & & & \\
\hline Level of education & & & 2.79 & 0.4249 & NO \\
\hline Primary & 10.2 & 9.2 & & & \\
\hline Secondary & 17.4 & 20.4 & & & \\
\hline Higher & 15.3 & 26.5 & & & \\
\hline Postgraduate & 1.0 & 0.0 & & & \\
\hline \multicolumn{6}{|l|}{ II. Career abroad } \\
\hline Host country & & & 4.61 & 0.2028 & NO \\
\hline United States & 8.2 & 4.1 & 2.85 & 0.0911 & $*$ \\
\hline Spain & 29.6 & 43.9 & & & \\
\hline Italy & 0.0 & 2.0 & & & \\
\hline United Kingdom & 6.1 & 6.1 & & & \\
\hline Wage & $1774.46^{\mathrm{a}}$ & $1181.85^{\mathrm{a}}$ & 1.64 & 0.2004 & NO \\
\hline Stay $>9$ years & 34.7 & 46.9 & 0.332 & 0.5644 & NO \\
\hline Received training & 2.0 & 7.1 & 1.870 & 0.1717 & NO \\
\hline Entrepreneur in host country & 8.2 & 1.0 & 8.07 & 0.0045 & $* * *$ \\
\hline \multicolumn{6}{|l|}{ III. Return } \\
\hline Voluntary return & 35.7 & 33.8 & 5.15 & 0.0233 & ** \\
\hline Time since return $>9$ years & 13.3 & 8.2 & 3.49 & 0.0617 & $*$ \\
\hline \multicolumn{6}{|l|}{ IV. Current situation } \\
\hline Satisfied with return & 39.8 & 48.0 & 0.61 & 0.4344 & $\mathrm{NO}$ \\
\hline Familiar with SENAMI & 12.2 & 13.3 & 0.23 & 0.6321 & NO \\
\hline Help from SENAMI & 22.5 & 22.5 & 1.20 & 0.2727 & NO \\
\hline \multicolumn{6}{|l|}{ V. Re-emigration } \\
\hline Intention to re-emigrate & 15.3 & 25.5 & 1.10 & 0.2932 & $\mathrm{NO}$ \\
\hline
\end{tabular}

Source: Prepared by the authors, on the basis of S. Alarcón and others, Características socioeconómicas de los migrantes retornados en Loja (Ecuador), Madrid, Polytechnic University of Madrid, 2013 [online] http://blogs.upm.es/gedr/wp-content/uploads/sites/22/2014/06/ Migrantes-Retornados-Loja.pdf.

Note: The asterisks indicate rejection of the null hypothesis of homogeneously to a significance level of $10 \%(*), 5 \%(* *)$ and $1 \%(* * *)$. SENAMI: National Secretariat for Migrants.

a Average wage in dollars.

Table 4 shows entrepreneurship rates as a function of labour activity before, during and after migration, along with the corresponding hypothesis tests. Before leaving the country, entrepreneurs were working primarily in transportation (19\%), commerce (13\%) and agriculture (13\%), representing together $45 \%$ of the total. During their time abroad these people worked in hotels and restaurants (23\%), domestic service (21\%), agriculture (14\%) and construction (12\%), representing together $70 \%$ of the total. Upon their return there is no evidence that they are engaged in domestic service or construction: $39 \%$ of the total are working in "commerce, vehicle repair and personal services", while the remainder are occupied in transportation, and hotels and restaurants. 
Branch of activity before and during migration and after return

(Percentages of the total sample)

\begin{tabular}{|c|c|c|c|c|c|}
\hline & Entrepreneur & Non-entrepreneur & $\begin{array}{l}\text { chi-squared statistic } \\
\text { (Kruskal-Wallis) }\end{array}$ & $p$-value & $\begin{array}{l}\text { Homogeneity } \\
\text { rejected }\end{array}$ \\
\hline VI. Branch of activity before migration & & & 17.3 & 0.2403 & NO \\
\hline $\begin{array}{l}\text { Agriculture, livestock, etc. } \\
\text { Mining and quarrying }\end{array}$ & $\begin{array}{r}12.9 \\
0.0\end{array}$ & $\begin{array}{l}6.3 \\
6.3\end{array}$ & 1.33 & 0.2481 & NO \\
\hline Construction & 3.2 & 6.3 & 0.0308 & 0.8608 & NO \\
\hline Commerce, vehicle repair, etc. & 12.9 & 0.0 & 1.33 & 0.2481 & NO \\
\hline Hotels and restaurants & 9.7 & 6.3 & 1.62 & 0.2026 & $\mathrm{NO}$ \\
\hline Transport, storage, etc. & 19.4 & 18.8 & 1.16 & 0.2807 & NO \\
\hline Financial intermediation & 3.2 & 0.0 & & & \\
\hline Real estate & 3.2 & 0.0 & & & \\
\hline Public administration & 3.2 & 31.3 & 3.45 & 0.0634 & * \\
\hline Teaching & 9.7 & 25.0 & 1.96 & 0.1617 & NO \\
\hline Social and health services & 3.2 & 0.0 & 0.138 & 0.71 & NO \\
\hline Other community activities & 6.5 & 0.0 & & & \\
\hline Craftwork & 6.5 & 0.0 & & & \\
\hline Not specified & 6.5 & 0.0 & & & \\
\hline Total & 100.0 & 100.0 & & & \\
\hline VII. Branch of activity during migration & & & 28.46 & 0.0123 & $* *$ \\
\hline Agriculture, livestock, etc. & 14.0 & 0.0 & 5.3 & 0.0213 & $* *$ \\
\hline Social services & 4.7 & 8.3 & 2.55 & 0.1102 & NO \\
\hline Other community activities & 7.0 & 4.2 & & & \\
\hline Domestic service & 20.9 & 20.8 & 0.837 & 0.3602 & NO \\
\hline Mining and quarrying & 2.3 & 0.0 & & & \\
\hline Manufacturing & 9.3 & 8.3 & 0.533 & 0.4653 & NO \\
\hline Construction & 11.6 & 37.5 & 3.6 & 0.0578 & * \\
\hline Commerce, vehicle repair, etc. & 2.3 & 0.0 & & & \\
\hline Hotels and restaurants & 23.3 & 16.7 & 3.7 & 0.0545 & $*$ \\
\hline Transport, storage, etc. & 4.7 & 4.2 & & & \\
\hline Total & 100.0 & 100.0 & 100.00 & & \\
\hline VIII. Branch of activity after return & & & 58.27 & 0.0000 & $* * *$ \\
\hline Manufacturing & 4.5 & 4.2 & 0.646 & 0.4215 & NO \\
\hline Construction & 2.3 & 8.3 & 0.138 & 0.7100 & NO \\
\hline Commerce, vehicle repair, etc. & 38.6 & 0.0 & 26 & 0.0000 & $* * *$ \\
\hline Hotels and restaurants & 9.1 & 12.5 & 0.533 & 0.4653 & NO \\
\hline Transport, storage, etc. & 11.4 & 25.0 & 0.0124 & 0.9114 & NO \\
\hline Public administration & 0.0 & 8.3 & & & \\
\hline Teaching & 2.3 & 12.5 & 0.597 & 0.4396 & NO \\
\hline Social services & 11.4 & 12.5 & 0.0013 & 0.9715 & NO \\
\hline Other community activities & 18.2 & 12.5 & & & \\
\hline Craftwork & 2.3 & 0.0 & & & \\
\hline Not specified & 0.0 & 4.2 & & & \\
\hline Total & 100.0 & 100.0 & & & \\
\hline
\end{tabular}

Source: Prepared by the authors, on the basis of S. Alarcón and others. Características socioeconómicas de los migrantes retornados en Loja (Ecuador), Madrid, Polytechnic University of Madrid, 2013 [online] http://blogs.upm.es/gedr/wp-content/uploads/sites/22/2014/06/ Migrantes-Retornados-Loja.pdf.

Note: The asterisks indicate rejection of the null hypothesis of homogeneously to a significance level of $10 \%(*), 5 \%(* *)$ and $1 \%(* * *)$.

Those who do not become entrepreneurs are more likely to have been engaged in more specialized activities before they left. In comparison with those who started businesses, these people worked for the most part in public administration (31\%), teaching (25\%) and transport and storage (19\%), representing together $75 \%$ of the total. In the country of destination, these persons performed activities similar to those of the entrepreneurial group, i.e. construction $(38 \%)$, domestic service $(21 \%)$ and hotels and restaurants $(17 \%)$. There is clearly a loss of human capital associated with the kind of activity performed in the host country for the time they remained abroad. This is evident in the activity they performed after emigrating, working primarily (in equal shares of $12 \%$ ) in "transport, storage and communications", "hotels and restaurants" and "personal and social 
services and education". It is interesting to note that, before leaving, $25 \%$ were engaged in teaching, while upon return only $12 \%$ pursued this activity.

The tests conducted (see table 4) indicate that the branch of work prior to migration has no influence on entrepreneurship after return, but it does have an influence on the type of work performed during migration and upon returning to the country. The tests indicate in fact that those who worked in "public administration, defence and social security" before emigrating exhibit significantly lower rates of entrepreneurship upon their return. During migration, the activities that significantly boost the probability of future entrepreneurship are agriculture and hotels and restaurants, while persons who engaged in construction have lower rates of entrepreneurship. With respect to occupational activities after return, entrepreneurship is associated with commerce, vehicle repairs and personal services.

\section{IV}

\section{Econometric model}

\section{Specification}

Entrepreneurship involves knowledge, effort and investment. Knowledge refers to practical skills and experience with productive or commercial processes acquired in the past (before, during or after migration). Effort includes dealing with processes and formalities for starting a business, as well as complementary training, and adapting the products or services of the business to market demand. Investment, for its part, depends on savings and on borrowing capacity, and once made it represents a sunk cost in most cases.

The decision to start a business thus entails costs and risks that not everyone is prepared to assume. A returnee will decide to start a business if the expected benefits are greater than those that could be obtained from paid employment or from being idle. The empirical model proposed is a binary-choice probit model designed to identify and quantify the factors that enhance the probability that a returnee will launch a business:

$$
\begin{aligned}
& \left.\operatorname{Prob}_{\text {business }_{j}}=1\right)=\Phi\left(a_{i} A_{i j}+b_{i} B_{i j}+\ldots+g_{i} G_{i j}+\varepsilon_{i t}\right) \\
& \operatorname{Prob}_{\left(\text {business }_{j}=0\right)=1-\Phi(.)}
\end{aligned}
$$

The sub-index $i$ indicates variable and $j$ indicates returning migrant. The variable business takes the value 1 if a business is started, and otherwise is zero (paid employee or unemployed). $\Phi$ represents the normal standard distribution function. The explanatory variables are grouped in the same blocks of tables 3 and 4, although in each of them we have taken those that showed the greatest differences between entrepreneurs and nonentrepreneurs. The group $H$ of occupational activities after return has been excluded to avoid problems of simultaneity with the dependent variable. $a_{i}, b_{i}, \ldots, g_{i}$ are the coefficients of the explanatory variables that are estimated using the maximum likelihood method.

The demographic variables $\left(A_{i}\right)$ include sex, age, civil status and level of education. To avoid introducing too many regressors, in the last two we have taken only civil status and a higher education degree, as these show the greatest differences between entrepreneurs and non-entrepreneurs in table 3 . The age variable has been taken in linear and squared form in order to expand the possibilities of its effects.

Career abroad $\left(B_{i}\right)$ includes the migratory destination (in this case the United States), wages - which are considered a proxy for accumulated savings and hence for the capacity for self-financing - and dummy variables that indicate whether the duration of the stay abroad exceeded nine years, whether some type of training was received, and whether a business was launched during the stay abroad. For wages we introduce a squared term in order to consider non-linear effects.

In the return block $\left(C_{i}\right)$ we include a variable that indicates whether the decision was voluntary in the face of legal, economic or health problems, as well as the time elapsed since the return to Ecuador and, specifically whether it exceeded nine years. With respect to these two variables, it must be remembered that the survey was conducted in 2012 and therefore includes not only the most recent crisis-impelled returnees but also many who returned spontaneously.

The current situation block $\left(D_{i}\right)$ and the re-emigration block $\left(E_{i}\right)$ include dummies associated with satisfaction with the return, institutional knowledge (familiarity with SENAMI), the willingness to accept institutional aid (SENAMI assistance) and the intention to re-emigrate. 
In the blocks related to occupational activities $\left(F_{i}\right.$ and $G_{i}$ ) we have included only those that showed the greatest differences in table 4, i.e. working in public administration before emigration and working in agriculture and the hospitality industry during the stay abroad.

In an effort to delve further into the decision to start a business, we have also estimated this model at the two levels. To do so, we have taken as explanatory variables the categories of own-account worker and employer. In the first case, in principle, the intention is to start a small business as a means of livelihood, while in the second case we are dealing with small enterprises that generate jobs and imply a greater capacity in terms of know-how, experience or financing, and that will have a greater impact on local development.

\section{Results}

The results for the three models are presented in table 5. The goodness-of-fit measures indicate that the regressors considered are capable of explaining an important part of returnees' decisions. Thus, McFadden's pseudo $\mathrm{R}^{2}$ coefficients indicate that the variables as a whole are significant in all three cases, with values greater than those from other studies. For example, Gubert and Nordman (2011) obtain pseudo R-squared values of $0.29,0.30$ and 0.35 for their models of post-return entrepreneurship in Algeria, Morocco and Tunisia, respectively, while Black and Castaldo (2009) report 0.28 for Ghana and 0.58 for Côte d'Ivoire. In this study most of these values are exceeded for the entrepreneurs model (pseudo R-squared $=0.5484$ ) and the employer's model (0.5606). On the other hand, the proportion of individuals classified correctly using the prediction from the models is also high, varying between $87.23 \%$ for employers and own-account workers and $85.71 \%$ in the case of entrepreneurs.

Under demographic characteristics, the female gender variable takes a negative value in the entrepreneur and own-account regressions, but it does not reach significance. In other cultures, gender produces significant differences: for example in the countries of North Africa, Gubert and Nordman (2011) find that the probability of becoming an entrepreneur is $25 \%$ lower for female returnees in Morocco, and 34\% lower in Tunisia, while McCormick and Wahba (2001) show a likelihood 16\% higher for men; in this study the values are much lower, and are not backed by statistical evidence. Therefore, no reportable differences between men and women are detected.
Civil status turns out not to be significant, but higher education, by contrast, has a negative impact in relation to primary and secondary education levels. Thus, the probability of being an entrepreneur is $18 \%$ lower among those with a university education, although in the other two models we find that it affects only employers and not own-account workers. A possible explanation is that higher education provides access to paid employment, private or public, with sufficient and stable remuneration for a moderate standard of living. This means that such persons do not need to run the risk of becoming an entrepreneur in order to boost their income level. In other studies, the results are not conclusive: Gubert and Nordman (2011), for example, find that a university education enhances the probability of becoming an entrepreneur among returnees in Algeria and Morocco, but not among those in Tunisia, where the reverse occurs. The findings of McCormick and Wahba (2001) are similar to those of this study: they conclude that the higher the level of education the lower the probability of becoming an entrepreneur in Egypt. Piracha and Vadean (2010), in their study of Albanian returnees, find that university education improves the probability of paid employment, while a secondary education favours entrepreneurship.

The age factor has been introduced in the probit models with a linear term as well as a quadratic term to capture possible non-linear effects. In the own-account and employer models both terms are significant. Figure 1 (panels A and C) helps to understand how this variable works, showing for each age the probability of being an own-account worker (entrepreneur) in dark grey and the probability of not being one in light grey. This representation allows us to see how the probability of being an own-account worker is greater at the beginning and at the end of working life, as it reaches a maximum between 25 and 30 years of age, declines to a minimum between ages 40 and 45, and then starts to rise again, reaching another peak after age 60 . The diagram of the probability of being an employer is different: although it reaches a peak between 30 and 35 years of age, it then declines only to rise progressively to reach its maximum between age 45 and 50, after which age it again declines. Ilahi (1999) finds that age has a negative impact, as it is associated positively with work experience and with higher earnings as an employee. The idea of a positive effect also seems plausible, as management capacity, and hence the ability to start a business, improves with age (Gubert and Nordman, 2011). Our results exceed these expectations. Thus, 
in the own-account model we identify marginally negative effects up to 40-45 years, and positive effects after that age, which indicates that paid employment is indeed preferred but that it is hard to find after 45 years of age, at which point the alternative of becoming an own-account worker emerges as an alternative for earning a living. The employer model shows marginally positive effects with age for those who have a greater entrepreneurial bent, but it reaches a maximum at age 50 .

TABLE 5

Probit model estimation of the probability of becoming an entrepreneur, own-account worker or employer after return

\begin{tabular}{|c|c|c|c|c|c|c|}
\hline & \multicolumn{2}{|c|}{ Entrepreneur } & \multicolumn{2}{|c|}{ Own-account } & \multicolumn{2}{|c|}{ Employmentloyer } \\
\hline & $\begin{array}{c}\text { Marginal } \\
\text { effect }\end{array}$ & $z$-value & $\begin{array}{c}\text { Marginal } \\
\text { effect }\end{array}$ & $z$-value & $\begin{array}{c}\text { Marginal } \\
\text { effect }\end{array}$ & $z$-value \\
\hline Independent term & -0.3344 & -0.5010 & 1.5220 & $1.8560^{*}$ & -2.4556 & $-2.5690 * *$ \\
\hline \multicolumn{7}{|l|}{ I. Demographic characteristics } \\
\hline Female & -0.0859 & -1.0310 & -0.1112 & -1.3100 & 0.0431 & 0.5170 \\
\hline Age & 0.0199 & 0.6940 & -0.0840 & $-2.3910 * *$ & 0.1140 & $2.6140 * * *$ \\
\hline $\mathrm{Age}^{2}$ & -0.0002 & -0.6510 & 0.0009 & $2.3760 * *$ & -0.0013 & $-2.5130 * *$ \\
\hline Married & 0.1066 & 1.3830 & -0.0628 & -0.8110 & 0.0781 & 1.0850 \\
\hline Higher education & -0.1783 & $-2.2080 * *$ & 0.0946 & 1.0980 & -0.1733 & $-2.0290 * *$ \\
\hline \multicolumn{7}{|l|}{ II. Career abroad } \\
\hline Spain & -0.0757 & -0.5150 & 0.1359 & 1.1300 & -0.2399 & $-1.8940 *$ \\
\hline Italty & -1.1205 & -0.0160 & -0.5822 & -0.0050 & -1.2403 & 0.0000 \\
\hline United Kingdom & -0.2856 & -1.4980 & 0.0835 & 0.4930 & -0.2527 & -1.6020 \\
\hline Wage & -0.0007 & $-2.1590 * *$ & 0.0000 & 0.0210 & -0.0003 & $-1.9520^{*}$ \\
\hline Wage $^{2}$ & 0.0000 & $2.0310^{* *}$ & 0.0000 & -0.3410 & 0.0000 & $2.3950 * *$ \\
\hline Stay $>9$ years & -0.0095 & -0.0990 & -0.0314 & -0.3420 & -0.0174 & -0.1950 \\
\hline Received training & -0.3692 & $-1.8310^{*}$ & -1.2132 & -0.0240 & 0.1792 & 0.7710 \\
\hline Entrepreneur during stay & 0.4324 & $2.3080 * *$ & 0.3622 & $2.4530 * *$ & 0.0418 & 0.3110 \\
\hline \multicolumn{7}{|l|}{ III. Return } \\
\hline Voluntary return & 0.2210 & $2.6370 * * *$ & 0.0753 & 0.9840 & 0.1454 & $1.8320^{*}$ \\
\hline Time since return $>9$ years & 0.0376 & 0.3290 & -0.0484 & -0.4420 & -0.0349 & -0.3320 \\
\hline \multicolumn{7}{|l|}{ IV. Current situation } \\
\hline Satisfied with return & 0.2228 & $1.9080^{*}$ & 0.0310 & 0.3810 & 0.1791 & 1.4690 \\
\hline Familiar with SENAMI & 0.1263 & 1.3930 & 0.1322 & 1.3830 & 0.0677 & 0.8180 \\
\hline Assistance from SENAMI & 0.1482 & 1.0360 & 0.0864 & 0.5930 & -0.0289 & -0.2470 \\
\hline \multicolumn{7}{|l|}{ V. Re-emigration } \\
\hline Intention to re-emigrate & -0.2096 & $-2.2660 * *$ & -0.1991 & $-2.0600 * *$ & -0.0547 & -0.6520 \\
\hline \multicolumn{7}{|c|}{ VI. Branch of activity before migration } \\
\hline Public administration & -0.4177 & $-2.3320 * *$ & 0.0817 & 0.6360 & -1.3789 & 0.0000 \\
\hline \multicolumn{7}{|c|}{ VII. Branch of activity during stay abroad } \\
\hline Agriculture & 0.3951 & $2.4590 * *$ & 0.0709 & 0.5720 & 0.3142 & $2.2110 * *$ \\
\hline Hospitality industry & 0.5192 & $2.9110 * * *$ & 0.0543 & 0.4800 & 0.3386 & $2.9160 * * *$ \\
\hline Pseudo $R^{2}$ & 0.5484 & & 0.3340 & & 0.5606 & \\
\hline Correctly classified & $85.7 \%$ & & $87.2 \%$ & & $87.2 \%$ & \\
\hline
\end{tabular}

Source: Prepared by the authors, on the basis of S. Alarcón and others, Características socioeconómicas de los migrantes retornados en Loja (Ecuador), Madrid, Polytechnic University of Madrid, 2013 [online] http://blogs.upm.es/gedr/wp-content/uploads/sites/22/2014/06/ Migrantes-Retornados-Loja.pdf.

Note: The asterisks indicate rejection of the null hypothesis of homogeneously to a significance level of $10 \%(*), 5 \%(* *)$ and $1 \%(* * *)$. 
FIGURE 1

Representation of business decisions as a function of age and wage

Panel A. Own-account

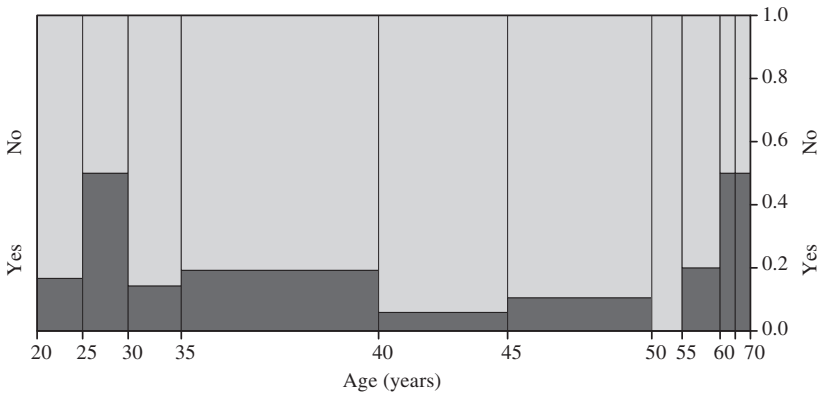

Panel C. Employer

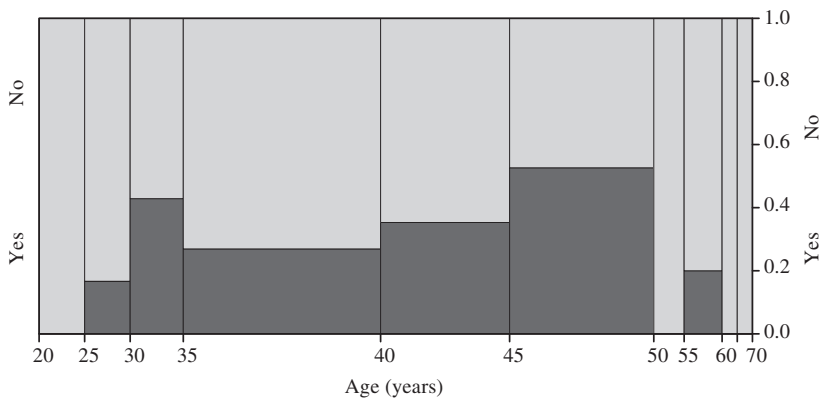

Panel B. Entrepreneur

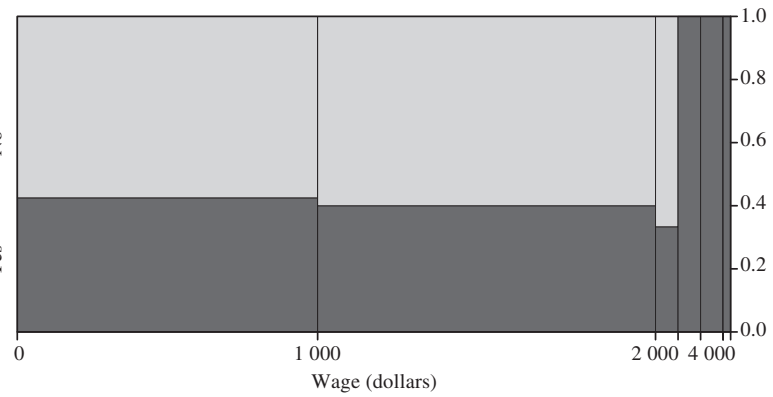

Panel D. Employer

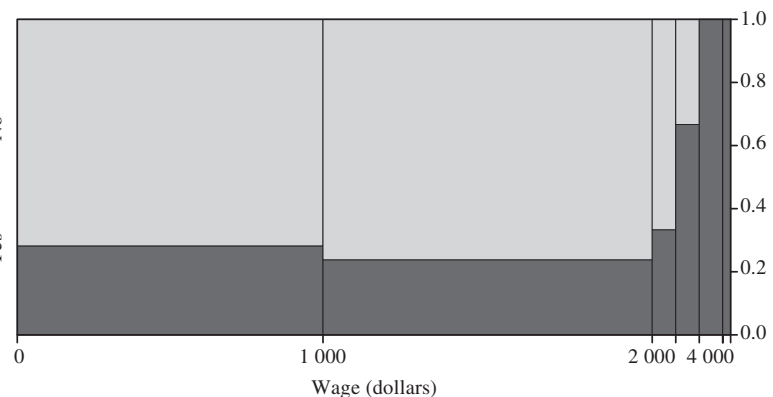

Source: Prepared by the authors, on the basis of S. Alarcón and others, Características socioeconómicas de los migrantes retornados en Loja (Ecuador), Madrid, Polytechnic University of Madrid, 2013 [online] http://blogs.upm.es/gedr/wp-content/uploads/sites/22/2014/06/ Migrantes-Retornados-Loja.pdf.

In examining careers abroad, we have taken the United States as the default destination. In the entrepreneur and own-account models, the destinations of Spain, Italy and the United Kingdom take negative values vis-à-vis the United States, although these are not significant. Yet the Spain variable in the employer model is both negative and significant. We find, then, that Lojanos who spent time in that country have a lower tendency to become employers, compared to those who emigrated to the United States.

As was the case with the age factor, wage levels abroad have been introduced in the regressions as a squared term, and non-linear behaviour was identified in the entrepreneur and employer models, where both coefficients (linear and squared) are significant. In fact, panels B and D of figure 1 show a non-linear path that trends downward for lower wage levels and then rises: thus the probability declines at the beginning, as it is slightly lower for wages between US\$1,000 and US\$2,000 than for those below US\$1,000, but after the level of US $\$ 3,000$ for entrepreneurs and US $\$ 2,000$ for employers the probability rises in step with the increase in wage received in the host country. Therefore, the fact of having secured economic resources abroad is decisive for financing an enterprise. This outcome is consistent with other studies (McCormick and Wahba, 2001; Black and Castaldo, 2009; Démurger and Xu, 2011) which find that savings have a clearly positive and significant influence on business start-ups by returnees.

The duration of the migration has no statistical significance in any of the three regressions. Although in theory a positive link to entrepreneurship seems plausible, as a longer stay allows technical and business skills to be acquired, the empirical studies do not fully support this idea. McCormick and Wahba (2001) study this variable in depth, considering it potentially endogenous, and they find evidence of a positive association but only for those Egyptian returnees with higher levels of education. Gubert and Nordman (2011) discard the impact of the duration of migration on entrepreneurship among returnees to Algeria and Morocco, and find positive evidence only in Tunisia. Nor do Black and Castaldo (2009) find any evidence in sub-Saharan Africa. 
The variable of having received some form of training during migration is significant in the entrepreneur model, but it has a negative sign. Once again, the empirical studies find evidence both positive (Gubert and Nordman, 2011) and negative (Black and Castaldo, 2009): depending on the situation on the labour market in the home country, education may be an incentive either to create a business or to continue in paid employment. In the case of Loja, more education would seem to augment the probability of the latter option.

The variable of having been an entrepreneur abroad is positive and significant in the entrepreneur model and in the own-account model: in the former it is positive but not sufficiently so to be significant. We can confirm, then, that entrepreneurial experience during emigration is an important factor: specifically, it boosts by $42 \%$ the probability of becoming an entrepreneur upon return. These marginal effects are greater than those in other studies: for example Gubert and Nordman (2011) report a 27\% increase for Algerians (19-18\% for Moroccans and Tunisians). McCormick and Wahba, 2001) find a marginal effect of 55\%, but in a variable of having been an entrepreneur prior to emigration.

With respect to the conditions of return, voluntary motives (and not those driven by legal, economic or health concerns) show a clearly positive and significant relationship with the dependent variables. Thus, if the returnees came back voluntarily the probability of starting a business rises by $22 \%$, and that of being an employer by $15 \%$. Black and Castaldo (2009) report

\section{V}

\section{Conclusions}

This study offers information on the contribution that return migration is making to local development in Ecuador. Specifically, using a survey of returnees conducted in 2012, we examined which are the factors related with the decision to start a business in the Canton of Loja. We performed a more intuitive analysis, commenting directly on the results of the survey and carrying out univariate tests and, subsequently, a more in-depth multivariate analysis estimating probit models. In order to make the outcomes more robust, we have used different meanings of "entrepreneur:" a broader concept that includes ownaccount workers and employers, and a narrower concept that is confined to employers alone. marginally positive effects of $5 \%$ among those who return for family reasons.

As to the current situation, the variable of being satisfied with one's return is positive in all three cases, but significant only for the entrepreneur model. The variable of institutional familiarity with SENAMI is also positive but does not reach the significance threshold. The variable of being willing to accept SENAMI assistance does not appear significant in any of the cases, but interestingly enough it takes a negative sign for the employer model.

The variable of intending to re-emigrate is negative in the three cases, and significant for the first two models. This corroborates what would anyway seem normal and logical: plans to emigrate once again effectively exclude the possibility of launching a business in Ecuador and, more concretely, of establishing oneself as an ownaccount worker.

With respect to occupational activities, those who worked in public administration before leaving Ecuador have a significantly lower probability of starting a business. McCormick and Wahba (2001) obtain a similar result, but they report a marginal effect that diminishes the probability of entrepreneurship by $16 \%$, while in this study the effect is much greater, at $42 \%$. On the other hand, the fact of having worked in agriculture and the hospitality industry during emigration produces marginally positive and significant effects on the probabilities of being an entrepreneur and employer. We find, then, that a productive return is also associated with occupational activities performed abroad and with the experience acquired from them.

Among the demographic characteristics, the most important are age and level of education, and there are no great differences between men and women, and only scant differences by civil status. With respect to age, we found a non-linear behaviour: the probability that a returnee will become an own-account worker declines to age 45 and then rises progressively until retirement. The probability of becoming an employer rises with age until 50 years, and then declines. Persons with a university education are less likely to be entrepreneurs and employers, probably because they can more readily find well-paid work as employees. 
Among the variables relating to the working career abroad, the most significant is the wage earned in the host country, which we have taken as a measure of saving and self-financing capacity. The probability of becoming an entrepreneur and an employer upon return decreases up to salaries of US $\$ 3,000$ a month, but then rises progressively for higher levels of income. It is this factor that marks the difference between employers and own-account workers: the high level of income earned makes it possible to accumulate more savings, which can be used to start a business and to generate employment.

One variable that turns out to be very influential is entrepreneurial experience, which considerably increases the probability of becoming an entrepreneur or own-account worker.

The reason for return also seems to be a variable that has an impact on the future working career. Thus, those who returned voluntarily, whether for family reasons or by their own volition, have higher rates of entrepreneurship as well as job creation, whereas if the motivation was illness or legal problems the returnee is more likely to end up as an employee or idle. While the univariate analysis offers some evidence that the probability of entrepreneurship rises with the time elapsed since returning to Ecuador, this factor does not appear significant when considered jointly with other variables in the probit regressions. On the other hand, persons who are thinking of returning to the host country are less likely to start a business or, more concretely, to become own-account workers.

When it comes to the occupational activities performed, we again find clear linkages with the occupational situation after return. Those who worked in public administration before emigrating are less likely to start a business upon return, and the majority of such businesses are launched by Ecuadorians who worked in agriculture or the hospitality industry in the host country.

Lastly, this article shows that migratory experience by itself offers no guarantee of success in entrepreneurial initiatives, nor does it ensure transfers of capital or know-how that will boost economic development in the home region. Only in very specific circumstances may we speak of the capacity to generate employment and development. Consequently, policies intended to foster entrepreneurship should not focus on the community of returned migrants, but should cover the entire Ecuadorian population. This study has however identified the characteristics of certain returnees who indeed make contributions to self-employment or the creation of micro-enterprises. These persons constitute human capital that should be valued and put to use, for they are transferring know-how or capital accumulated during their stay abroad, and they can be considered as engines of development in their home region.

\section{Bibliography}

Alarcón, S. and M. Fernández (coords.) (2013), Diagnóstico para el fortalecimiento institucional de los gobiernos locales en Ecuador, La Catarata.

Alarcón, S. and others (2013), Características socioeconómicas de los migrantes retornados en Loja (Ecuador), Madrid, Polytechnic University of Madrid [online] http://blogs.upm. es/gedr/wp-content/uploads/sites/22/2014/06/MigrantesRetornados-Loja.pdf.

Amuedo-Dorantes, C. and S. Pozo (2006), "Remittance receipt and business ownership in the Dominican Republic", The World Economy, vol. 29, No. 7, John Wiley \& Sons.

Biernacki, P. and D. Waldorf (1981), "Snowball sampling: problems and techniques of chain referral sampling", Sociological Methods \& Research, vol. 10, No. 2, SAGE Publications.

Black, R. and A. Castaldo (2009), "Return migration and entrepreneurship in Ghana and Côte d'Ivoire: the role of capital transfers", Tijdschrift voor economische en sociale geografie, vol. 100, No. 1, John Wiley \& Sons.

Cerase, F. (1974), "Expectations and reality: a case study of return migration from the United States to Southern Italy", International Migration Review, vol. 8, No. 2, John Wiley \& Sons.

Chandra, V.P. (1997), "Remigration: return of the prodigals - An analysis of the impact of the cycles of migration and remigration on caste mobility", International Migration Review, vol. 31, No. 1, The Center for Migration Studies of New York, Inc.
Constant, A. and D.S. Massey (2002), "Return migration by German guestworkers: neoclassical versus new economic theories", International Migration, vol. 40, No. 4, John Wiley \& Sons.

Correa, R. (2010), "Familia y migración: características socio económicas de los migrantes internacionales del Cantón Loja en Ecuador y sus familias", Revista Fuente, vol. 1, No. 3, Autonomous University of Nayarit.

Démurger, S. and H. Xu (2011), "Return migrants: the rise of new entrepreneurs in rural China", World Development, vol. 39, No. 10, Amsterdam, Elsevier.

Diatta, M. and N. Mbow (1999), "Releasing the development potential of return migration: the case of Senegal", International Migration, vol. 37, No. 1, John Wiley \& Sons.

Fernández Guzmán, E. (2011), "Revisión bibliográfica sobre la migración de retorno", Norteamérica, vol. 6, No. 1, Mexico City, National Autonomous University of Mexico.

Glaser, W. and G. Habers (1974), "The migration and return of professionals", International Migration Review, vol. 8, No. 2, The Center for Migration Studies of New York, Inc.

Gmelch, G. (1980), "Return migration", Annual Review of Anthropology, vol. 9, Palo Alto, Annual Reviews.

Gmelch, G. and S. Gmelch (1995), "Gender and migration: the readjustment of women migrants in Barbados, Ireland, and Newfoundland", Human Organization, vol. 54, No. 4, Society for Applied Anthropology. 
Gubert, F. and C. Nordman (2011), "Return migration and small enterprise development in the Maghreb", Diaspora for Development in Africa, S. Plaza and D. Ratha (eds.), Washington, D.C., World Bank.

Hunt, J. (2004), "Are migrants more skilled than non migrants? Repeat, return, and same- employer migrants", Canadian Journal of Economics/ Revue canadienne d'économique, vol. 37, No. 4, John Wiley \& Sons.

Ilahi, N. (1999), "Return migration and occupational change", Review of Development Economics, vol. 3, No. 2, John Wiley \& Sons.

INEC (National Statistics and Census Institute) (2010), "VII Censo de Población y vi Vivienda", Quito.

IOM (International Organization for Migration) (2006), "Migración de retorno", Fundamentos de gestión de la migración, Geneva.

Kelley, D.J., S. Singer and M. Herrington (2012), Global Entrepreneurship Monitor. 2011 Global Report [online] http://www.gemconsortium. org/report.

Lee, A. (1974), "Return migration in the United States", International Migration Review, vol. 8, No. 2, John Wiley \& Sons.

Lockwood, V. (1990), "Development and return migration to rural French Polynesia", Migration Review, vol. 24, No. 2, The Center for Migration Studies of New York, Inc.

López de Lera, D. and A. Pérez Caramés (2013), "Is the Spanish crisis fostering the return of immigrants?", Migration Studies.

Marchetta, F. (2012), "Return migration and the survival of entrepreneurial activities in Egypt", World Development, vol. 40, No. 10, Amsterdam, Elsevier.

Martínez Pizarro, J. (2003), "El mapa migratorio de América Latina, las mujeres y el género", Población y Desarrollo series, No. 44 (LC/G.1974-P), Santiago, Economic Commission for Latin America and the Caribbean (ECLAC). United Nations publication, Sales No. S.03.II.G.133.

McCormick, B. and J. Wahba (2001), "Overseas work experience, savings and entrepreneurship amongst return migrants to LDCs", Scottish Journal of Political Economy, vol. 48, No. 2, John Wiley \& Sons.

Montoya, J., R. Salas and J.A. Soberón (2011), "La migración internacional de retorno en el estado de México: oportunidades y retos para el aprovechamiento socio productivo de sus capacidades", Suma de negocios, vol. 2, No. 2, Bogota, Konrad Lorenz Fundación Universitaria.

Muschkin, C. (1993), "Consequences of return migrant status for employment in Puerto Rico", International Migration Review, vol. 27, No. 1, The Center for Migration Studies of New York, Inc.
Nadeem, I. (1999), "Return migration and occupational change", Review of Development Economics, vol. 3, No. 2, John Wiley \& Sons.

Olesen, H. (2002), "Migration, return, and development: an institutional perspective", International Migration, vol. 40, No. 5, John Wiley \& Sons.

Piracha, M. and F. Vadean (2010), "Return migration and occupational choice: evidence from Albania", World Development, vol. 38, No. 8, Amsterdam, Elsevier.

Premachandra, A. (1990), "International contract migration and the reintegration of return migrants: the experience of Sri Lanka", International Migration Review, vol. 24, No. 2, The Center for Migration Studies of New York, Inc.

Ravenstein, E.G. (1885), "The laws of migration", Journal of the Statistical Society of London, vol. 48, No. 2, London, Royal Statistical Society.

Schramm, C. (2011), "Retorno y reinserción de migrantes ecuatorianos. La importancia de las redes sociales transnacionales", Revista CIDOB d'Afers Internacionals, vol. 93-94, Barcelona, Barcelona Centre for International Affairs (CIDOB).

Thomas-Hope, E. (1999), "Return migration to Jamaica and its development potential", International Migration, vol. 37, No. 1, John Wiley \& Sons.

UTPL (Universidad Técnica Particular de Loja) (2009), Estudio socioeconómico y de migración en Loja, Loja, Ecuador.

Vasco, C. (2011), "El impacto de la migración internacional y las remesas en la iniciativa emprendedora y la generación de empleo en el Ecuador rural", paper presented at the IV Congress of the International Migration and Development Network "Global Crisis and Migratory Strategies", Quito, Latin American Faculty of Social Sciences (FLACSO).

Verdera, F. and W. Sánchez (2009), Migraciones laborales internacionales: análisis de la metodología y resultados del módulo sobre migraciones laborales internacionales (MLI) en la Encuesta Nacional de Empleo y Desempleo Urbano de Ecuador, Lima, International Labour Organization (ILO).

Vono, D. (2011), "Panorama migratorio en España, Ecuador y Colombia a partir de las estadísticas locales", Migración internacional en América Latina y el Caribe. Nuevas tendencias, nuevos enfoques (LC/R.2170), J. Martínez Pizarro (ed.), Santiago, Economic Commission for Latin America and the Caribbean (ECLAC).

Wang, Z.C. and W.G. Yang (2013), "Self-employment or wageemployment? On the occupational choice of return migration in rural China", China Agricultural Economic Review, vol. 5, No. 2, Emerald. 